\title{
Aplasia of the optic nerve
}

\author{
Daniel CW Tang *, Eric MW Man, Sunny CS Cheng
}

\section{A B S T R A C T}

Aplasia of the optic nerve is an extraordinarily rare congenital anomaly that affects one or both optic nerves and is associated with the absence of the central retinal vessel and retinal ganglion cells. We report a case of unilateral optic nerve aplasia in a 4-month-old infant who was found to have left microphthalmos on routine postnatal checkup. Family history, antenatal history, and systemic evaluation were unremarkable. Magnetic resonance imaging showed absent left optic nerve with left microphthalmos. The optic chiasm was present and slightly deviated towards the right side. The remaining cerebral and ocular structures were normal.

\section{Hong Kong Med J 2015;21:366-8}

DOI: $10.12809 / \mathrm{hkmj} 144287$

DCW Tang ${ }^{*}, M B, B S$, FRCR

EMW Man, FRCR, FHKAM (Radiology)

SCS Cheng, FRCR, FHKAM (Radiology)

Department of Radiology, Pamela Youde Nethersole Eastern Hospital, Chai Wan, Hong Kong

* Corresponding author: tcw717@ha.org.hk

\section{Introduction}

Optic nerve aplasia is a very rare congenital anomaly that is typically unilateral, and is characterised by congenital absence of the optic nerve, central retinal vessels, and retinal ganglion cells. ${ }^{1}$ Bilateral cases are exceedingly rare. Various ocular anomalies are associated with it.

\section{Case report}

A female infant weighing $3225 \mathrm{~g}$ was born to a 26-year-old G1P1 female at full term via caesarean section because the umbilical cord was around the neck. She was found to have left microphthalmos on routine postnatal check-up in December 2013 in Hong Kong, at the age of 3 months. Family history was negative for ocular or other birth defects. Her mother was a housewife, with no history of any major illness during the pregnancy and antenatal workup was unremarkable. Physical examination was unremarkable with normal development for her age.

Eye examination of the infant at 4 months revealed left microphthalmos, and a left convergent
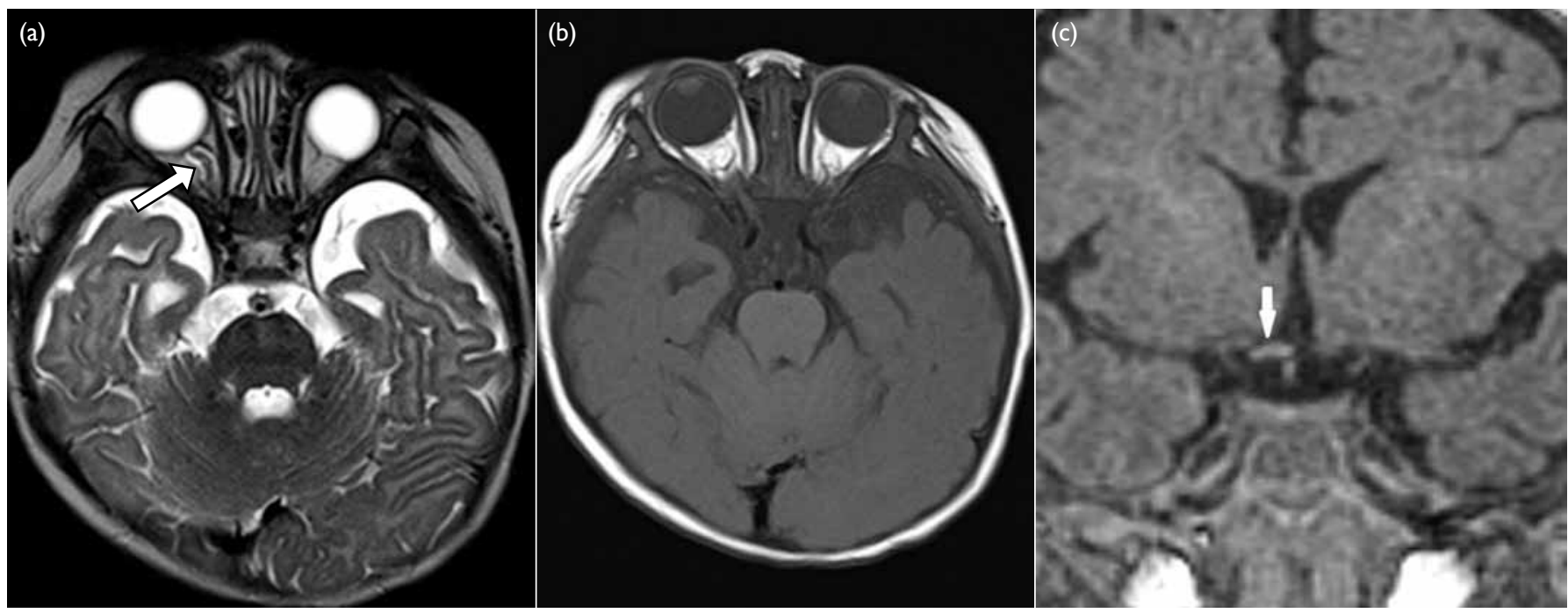

FIG I. (a) A T2-weighted axial magnetic resonance imaging (MRI) scan showing absence of the left optic nerve. The right optic nerve is present (arrow) and unremarkable. (b) A TI-weighted axial MRI scan showing the left globe is smaller in size than the right globe, compatible with left microphthalmos. (c) A TI-weighted coronal MRI scan showing deviation of the optic chiasm to the right side (arrow), which is related to the absence of left optic nerve 


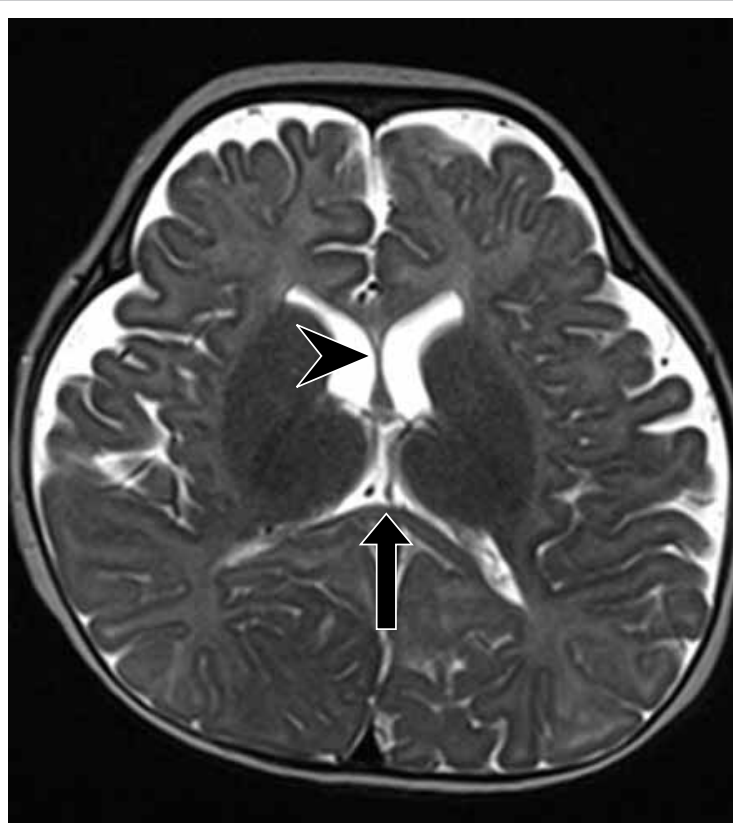

FIG 2. A T2-weighted axial magnetic resonance imaging scan showing intact septum pellucidum (arrowhead) and corpus callosum (arrow). No other intracranial abnormality is detected

squint with no definite visual following. The left pupil did not react to light stimulation and a persistent pupillary membrane was evident. Coloboma of the left optic disc was suspected. Fundus examination showed whitish choroidal atrophy with a flat optic disc on the left side. Right eye examination including fundus examination was unremarkable as were all blood tests and urinalysis.

Magnetic resonance imaging performed at 4 months revealed left microphthalmos, with no recognisable left optic nerve. The right optic nerve was present and normal in size. The optic chiasm was seen and slightly deviated towards the right side, likely related to the absence of the left optic nerve (Fig 1). Bilateral optic tracts and optic radiations were symmetrical. The septum pellucidum and corpus callosum were intact and all other cerebral and ocular structures were unremarkable (Fig 2).

\section{Discussion}

Aplasia of the optic nerve is a rare congenital anomaly that is typically unilateral. It occurs sporadically in an otherwise healthy person without sexual or racial predilection, ${ }^{2}$ or any evidence of an inherited factor.

Prenatal history is usually normal, but the possible influence of external factors such as episodes of viral infection in the first trimester, ${ }^{3}$ acetone exposure, or smoking during pregnancy ${ }^{4}$ cannot be excluded.

\section{視神經發育不全 \\ 鄧峻樺、萬民偉、鄭志成}

視神經發育不全是一種非常罕見的先天性異常疾病，可以影響一隻眼 睛或雙眼。這種病與患者缺乏視網膜中央血管和視網膜神經節細胞有 關。本文報告一名四個月大的嬰兒, 在產後常規檢查中發現左眼有小 眼球, 後確診為單側視神經發育不全。其家族史、產前史和全身評估 均為正常。磁共振成像顯示患者左眼有小眼球並缺少左視神經, 視交 叉稍微偏移向右側。患者的腦部和眼部的其餘結構均屬正常。

The pathogenesis of optic nerve aplasia remains unclear although it was first described 140 years ago. Scheie and Adler ${ }^{5}$ suggested that the defect in aplasia was failure of the mesoderm to enter the fetal fissure and provide vascularisation of the retina and nerve tissue. Weiter et $\mathrm{al}^{6}$ doubted the defective mesodermal development, since the dural sheath (a mesodermal derivative) was present in the majority of their cases. Instead, they suggested that the ventral invagination of the optic vesicle causes nerve fibre misdirection and secondary atrophy. Yanoff et $\mathrm{al}^{7}$ postulated a primary failure of the ganglion cell to develop and send out axons, resulting in a lack of induction of mesodermal ingrowth including a lack of retinal blood vessel development. Hotchkiss and Green $^{8}$ agreed that failure of mesodermal induction was secondary to third-order neuronal defect in the ganglion cell layer.

Plain X-ray can demonstrate a small optic foramen on the side of aplasia. ${ }^{9}$ Computed tomographic scan may show the globe and orbit on the affected side to be smaller than the normal side. Magnetic resonance imaging will show the absence of optic nerve on the affected side. The chiasm and lateral geniculate body may also appear small. ${ }^{10}$

Histopathological findings in optic nerve aplasia include the absence of ganglion cells and their axons as well as the absence of retinal vessels. ${ }^{7}$

According to many previous statements, aplasia of the optic nerve is a part of hypoplasia of the optic spectrum. According to an analysis performed by Alqahtani, ${ }^{2}$ of 42 cases in the literature, 29 were genuine aplasia of the optic nerve, while the remainder were hypoplastic optic nerve.

Unilateral aplasia of the optic nerve is often present in malformed eyes, with no abnormality in brain tissue. Possible malformations of the eye include microphthalmos, cataract, retinal dysplasia, coloboma of the iris and ciliary body, iris hypoplasia, malformation of the chamber angle, and persistent hyperplastic primary vitreous. ${ }^{11}$ No light perception is present in the affected eye and light stimulation 
elicits no direct or consensual pupillary response. Light stimulation of the normal eye results in a direct or consensual pupillary response. ${ }^{11}$ Possible malformation of the central nervous system includes hydranencephaly, orbital meningoencephalocele, and anencephaly. ${ }^{5,6}$

The prognosis of optic nerve aplasia is poor. There is no specific treatment and blindness occurs in the affected eye. Management of such cases is directed towards identifying any associated ophthalmological or neurological problems. Cavallini et $\mathrm{al}^{12}$ recommended ocular prosthesis in patients with associated microphthalmos, to enable normal development of the orbit, at least for aesthetic purposes.

Optic nerve aplasia should be suspected in a patient who presents with unilateral microphthalmos that is associated with the absence of central retinal vessels and ganglion cells. Magnetic resonance imaging is useful to screen for other associated intracranial abnormality.

\section{References}

1. Blanco R, Salvador F, Galan A, Gil-Gibernau JJ. Aplasia of the optic nerve: report of three cases. J Pediatr Ophthalmol
Strabismus 1992;29:228-31.

2. Alqahtani J. Optic nerve aplasia: a case report and literature review. J Pediatr Neurosci 2008;3:150-3.

3. Ginsberg J, Bove KE, Cuesta MG. Aplasia of the optic nerve with aniridia. Ann Ophthalmol 1980;12:433-9.

4. Barry DR. Aplasia of the optic nerves. Int Ophthalmol 1985;7:235-42.

5. Scheie HG, Adler FH. Aplasia of the optic nerve. Arch Ophthalmol 1941;26:61-70.

6. Weiter JJ, McLean IW, Zimmerman LE. Aplasia of the optic nerve and disk. Am J Ophthalmol 1977;83:569-76.

7. Yanoff M, Rorke LB, Allman MI. Bilateral optic system aplasia with relatively normal eyes. Arch Ophthalmol 1978;96:97-101.

8. Hotchkiss LH, Green WR. Optic nerve aplasia and hypoplasia. J Pediatr Ophthalmol Strabismus 1979;16:22540.

9. Little LE, Whitmore PV, Wells TW Jr. Aplasia of the optic nerve. J Pediatr Ophthalmol 1976;13:84-8.

10. Margo CE, Hamed LM, Fang E, Dawson WW. Optic nerve aplasia. Arch Ophthalmol 1992;110:1610-3.

11. Howard MA, Thompson JT, Howard RO. Aplasia of the optic nerve. Trans Am Ophthalmol Soc 1993;91:267-76; discussion 276-81.

12. Cavallini GM, Forlini M, Gramajo AL, et al. Optic nerve aplasia and microphthalmos: a case report. J Genet Syndr Gene Ther 2013;4:175. 